\title{
PEMETAAN DAERAH RAWAN KEBAKARAN HUTAN DAN LAHAN DI KABUPATEN ROKAN HILIR
}

\author{
Muhammad Ikhwan \\ Staf Pengajar Fakultas Kehutanan, Univeristas Lancang Kuning, Pekanbaru \\ JIn. Yos Sudarso Km.8 Rumbai, Pekanbaru, Riau, Telp/Fax (0761) 54092 \\ Email :mmighwan@yahoo.com
}

\begin{abstract}
Forest fire is one form of the disorder occur more frequently. The negative impact caused by forest fires large enough cover ecological damage, declining biodiversity, the decline in the economic value of forest and soil productivity, changes in micro and global climate and the smoke damage the health of people and disrupting transport by land, river, lake, sea and air. Given the impact of the forest fires, the efforts to protect the forest areas is very important. In an effort to control forest fires it is essential to map vulnerability to wildfires prepared to know which areas have the potential for fires. The purpose of this study was to map the vulnerability of land and forest fires in an effort to support the establishment of forest fire management strategy. Through a vulnerability map wildfires can provide vulnerability information to policy-making forest fire prevention / fire control and is expected to be the basis in prevention efforts as early as possible. The study was conducted from June until July 2014 and the case study research in Rokan Hilir Regency. Results of mapping the vulnerability of land and forest fires shows that most areas of Rokan Hilir Regency has a severe impact and the level of vulnerability is very high. Low-prone areas have extensive 9152.55 hectares (1.01\%), the rate of moderate-prone area of 158,943.95 hectares (17.49\%), high-level-prone area of 382,448.62 hectares (42.08\%) and very high levels of vulnerability with an area of 358,374.00 hectares (39.43\%).
\end{abstract}

Keyword : Forest fire, mapping

\section{PENDAHULUAN}

\section{Latar Belakang}

Kebakaran hutan merupakan salah satu bentuk gangguan yang makin sering terjadi. Dampak negatif yang ditimbulkan oleh kebakaran hutan cukup besar mencakup kerusakan ekologis, keanekaragaman hayati, merosotnya nilai ekonomi hutan dan produktivitas tanah, perubahan iklim mikro maupun global, dan asapnya mengganggu kesehatan masyarakat serta mengganggu transportasi baik darat, sungai, danau, laut dan udara. Kementerian Kehutanan menargetkan 
penurunan jumlah hotspot tahun 2014 di pulau-pulau rawan kebakaran lahan dan hutan yaitu Kalimantan, Sumatera, dan Sulawesi sebesar $59,2 \%$ dari ratarata hotspot tahun 2005-2009. Apabila rata-rata jumlah hotspot periode tahun 2005-2009 berjumlah 58.890 titik, maka target penurunan tersebut setara dengan 24.027 titik hotspot. Berdasarkan pemantauan yang dilakukan Direktorat Pengendalian Kebakaran Hutan, Direktorat Jenderal PHKA, periode tanggal 1 Januari 2013 hingga 31 Maret 2013, jumlah hotspot di pulau Kalimantan, Sumatera, dan Sulawesi terpantau sebanyak 2.672 titik. Salah satu indikator kinerja utama Kementerian Kehutanan sesuai rencana strategis Kementerian Kehutanan periode tahun 2010-2014 adalah penurunan jumlah hotspot di pulau Kalimantan, Sumatera, dan Sulawesi sebanyak $20 \%$ setiap tahun dari ratarata tahun 2005-2009.

Mengingat dampak kebakaran hutan tersebut, maka upaya perlindungan terhadap kawasan hutan sangatlah penting. Mengidentifikasi lebih awal kawasan hutan dan Iahan yang rawan terhadap kebakaran dengan didukung oleh sistem informasi yang tepat menjadi hal penting dalam upaya pencegahan kebakaran hutan dan lahan di Kabupaten Rokan Hllir. Penelitian ini dilaksanakan di wilayah Kabupaten Rokan Hilir, lokasi ini dipilih karena memiliki kerawanan kebakaran yang cukup tinggi.

\section{Tujuan}

Tujuan dari penelitian ini adalah untuk memetakan tingkat kerawanan kebakaran hutan dan lahan dalam upaya mendukung terwujudnya strategi penanggulangan kebakaran hutan.

\section{TINJAUAN PUSTAKA}

Kebakaran hutan adalah sebuah kejadian terbakarnya bahan bakar di hutan oleh api dan terjadi secara luas tidak terkendali. Syaufina (2008) mengemukakan bahwa kebakaran hutan adalah suatu kejadian di mana api melalap bahan bakar bervegetasi, yang terjadi di dalam kawasan hutan yang menjalar secara bebas dan tidak terkendali. Kebakaran hutan dibedakan pengertiannya dengan kebakaran lahan, dimana perbedaannya terletak pada lokasi kejadiannya. Kebakaran hutan yaitu kebakaran yang terjadi di dalam kawasan hutan, sedangkan kebakaran lahan adalah kebakaran yang terjadi diluar kawasan hutan (Pubowaseso, 2004). 
Tingkat kerawanan kebakaran hutan dan lahan merupakan suatu terminologi yang berhubungan dengan adanya peluang terjadinya kebakaran dan kondisi bahan bakar. Dalam kaitannya dengan bahan bakar, fire hazard digunakan untuk menyatakan keadaan kompleks bahan bakar yang ditentukan oleh volume, tipe, kondisi, keteraturan, dan lokasi yang menentukan derajat kemudahan pembakaran dan ketahanan terhadap pengendalian (Hardy, 2005).

Faktor lingkungan fisik dan aktivitas manusia merupakan dua kelompok utama faktor resiko kebakaran hutan dan lahan. Pusat perkampungan, jaringan jalan, jaringan sungai, tipe vegetasi dan penutupan lahan merupakan faktor manusia yang mempengaruhi tingkat resiko kebakaran hutan dan lahan (Boonyanuphap 2001). Lapan (2004) berhasil memetakan kelas kebakaran hutan dari yang sulit terbakar sehingga sangat mudah terbakar yaitu kelas kerawanan kebakaran sangat rendah, rendah, sedang, agak tinggi, tinggi dan sangat tinggi berdasarkan criteria dan bobot tertentu terhadap faktor-faktor penyebabnya.

Sistem Informasi Geografis adalah sistem komputer yang memiliki kemampuan untuk membangun, menyimpan, mengelola dan menampilkan informasi bereferensi geografis (Riyanto, 2009). Geographical Information System (GIS) disarankan sebagai alat yang cocok untuk memetakan distribusi data spasial dari bahaya kebakaran hutan. GIS dapat juga memadukan secara spasial beberapa peubah bahaya, seperti vegetasi, topografi dan sejarah kebakaran (Chuvieco and Salas, 1996)

\section{METODE PENELITIAN}

Penelitian ini dilaksanakan di wilayah Kabupaten Rokan Hilir yang merupakan daerah dengan hotspot lebih banyak dibandingkan dengan wilayah lain di Provinsi Riau. Analisis data dilakukan di Fakultas Kehutanan, Universitas Lancang Kuning. Pengumpulan data dilakukan pada bulan Juni 2014 sedangkan pengolahan data dilakukan pada bulan Juli 2014.

Bahan yang diperlukan dalam penelitian ini menggunakan data atribut dan data spasial di wilayah Kabupten Rokan Hilir yaitu : peta penutupan lahan tahun 2013, peta curah hujan, peta elevasi, peta lahan gambut, peta sebaran pemukiman, peta batas wilayah 
administrasi Kabupaten Rokan Hilir, peta jaringan jalan, Peta Sebaran Izin Usaha Pemanfaatan Hasil Hutan Kayu (IUPHHK), dan data sebaran hotspot tahun 2009-2014 dari satelit Aqua/Terra Modis. Alat yang digunakan pada penelitian ini adalah seperangkat personal computer (PC), Software pengolah data GIS yaitu ArcMap 10.1, Arc View 3.3, Microsoft Excel 2010. GPS, dan kamera dijital.

Tahap pengumpulan data meliputi : perolehan data spasial, kodifikasi data, penyeragaman sistem proyeksi peta, konversi format data sesuai dengan perangkat lunak yang dipakai dalam menjalankan prosedur Sistem Informasi Geografi (SIG). Input data yang digunakan sebagai peubah pembangun model adalah data spasial faktor biofisik, aktifitas manusia, data hot spot (titik panas) hasil olahan dari satelit Aqua/Terra MODIS. Parameterparameter yang digunakan untuk menentukan tingkat kerawanan adalah penutupan lahan (landcover), curah hujan, ketinggian tempat, dan lokasi pemukiman

Untuk tipe vegetasi atau penutupan lahan pemberian bobot dilakukan dengan berdasarkan kepada kepekaan tipe vegetasi yang bersangkutan terhadap terjadinya kebakaran. Nilai 1 diberikan kepada tipe vegetasi yang sangat peka yaitu yang sangat mudah terbakar, sampai nilai 7 untuk sulit terbakar. Pembobotan mengacu pada klasifikasi dan pembobotan yang dilakukan oleh Ruecker (2002), Hoffman (2000) serta Barus dan Gandasasmita (1996). Bobot untuk jenis penutupan lahan adalah $30 \%$.

Pembuatan peta kerawanan kebakaran hutan berdasarkan jenis tanah terdapat 2 kelas. Peta jenis tanah tersebut menganalisis dengan menggunakan sistem skoring. Klasifikasi skoring berdasarkan sifat atau karakteristik dari setiap jenis tanah gambut (nilai 1) dan non gambut (nilai 2). Bobot untuk jenis tanah adalah $25 \%$. Klasifikasi curah hujan dilakukan berdasarkan tipe iklim di daerah kabupaten Rokan Hilir. Untuk wilayah yang paling kering akan lebih sensitif untuk terbakar, khususnya pada waktu musim kemarau dan diberi nilai 1 , sedangkan wilayah yang paling basah tidak akan mudah terbakar walaupun mengalami musim kemarau yang panjang dan diberi nilai 5 . Bobot untuk kelas curah hujan adalah $25 \%$.

Ketinggian tempat dari 
permukaan laut diperoleh dari hasil derivasi Digital Elevation Model (DEM) resolusi 25 meter. Ketinggian tempat di atas permukaan laut diklasifikasikan dan diberi nilai bobot. Pada tempattempat yang rendah dikatakan mempunyai potensi yang tinggi untuk mudah terbakar dan diberi nilai 1 , seterusnya pada tempat yang lebih tinggi akan lebih sulit terbakar, sampai pada tempat tertinggi diberi nilai 6 . Bobot untuk ketinggian tempat adalah $10 \%$.

Peta jarak diperoleh dari proses buffering data lokasi pemukiman dengan menggunakan perangkat lunak ArcView. Peta batas pemukiman dalam bentuk shapefile diolah dengan menggunakan fitur create buffer pada menu theme, sehingga diperoleh peta jarak dari pemukiman (Nuarsa, 2005). Berdasarkan informasi yang diperoleh dari penelitian Arianti (2006), jarak tempuh terjauh yang dapat dicapai oleh manusia adalah $\pm 4 \mathrm{~km}$. Informasi ini dijadikan sebagai dasar untuk membagi kelas jarak dari pemukiman. Bobot untuk jarak terhadap pemukiman adalah 10\%. Untuk menghasilkan peta zonazona (daerah) bahaya kebakaran hutan dan lahan di Kabupaten Rokan Hilir, dari berbagai peta yang tersedia dan menunjang dilakukan sintesis yang berkaitan dalam suatu analisis tumpang susun dengan penilaian zona-zona bahaya kebakaran.

Peta Rawan Kebakaran merupakan model spasial yang digunakan untuk mempresentasikan kondisi di lapangan terkait dengan resiko terjadinya kebakaran hutan dan lahan. Model ini dibuat dengan menggunakan aplikasi GIS untuk memudahkan proses overlay antar faktor-faktor penyebab kebakaran. Oleh karena itu, memahami faktor-faktor penyebab dan perilaku kebakaran merupakan hal yang sangat utama di dalam melakukan permodelan ini (Solichin, dkk, 2007).

Mengingat keterbatasan data yang ada, pendekatan dilakukan dengan menerapkan beberapa asumsi untuk melengkapi keterwakilan data. Model peta rawan kebakaran ini tidak secara khusus memperhatikan potensi penyulutan, melainkan lebih secara luas memprediksi kemungkinan kebakaran akan terjadi serta kemungkinan intensitas serta dampak yang ditimbulkan. Potensi penyulutan juga dikembangkan sebagai salah satu komponen di dalam Sistem Analisa Ancaman Kebakaran (Ruecker, 2007) 
yang dikembangkan oleh South Project(SSFFMP).

Sumatra Forest Fire Management

Rawan Kebakaran $=\{30 \%$ * (Penutupan Lahan $)\}+\{25 \%$ * (Jenis Tanah $)\}+$ $\{25 \%$ * (Curah Hujan) $\}+\{10 \%$ * (Ketinggian Tempat) $\}+$ $\{10 \%$ * (Jarak Pemukiman) $\}$

(Solichin, dkk, 2007).

Kelas bahaya kebakaran hutan dan lahan ditentukan oleh penjumlahan dari semua nilai/bobot faktor-faktor (elemen) dalam suatu analisis tumpang susun.

Berdasarkan hasil skor kumulatif maka daerah rawan (potensial) kebakaran hutan dan lahan dikelompokkan ke dalam empat kelas seperti yang disajikan pada Tabel 1.

Tabel 1. Klasifikasi tingkat kerawanan kebakaran hutan dan lahan

\begin{tabular}{cc}
\hline Tingkat Kerawanan & Kelas \\
\hline Sangat Tinggi & $225-310$ \\
Tinggi & $311-396$ \\
Sedang & $397-482$ \\
\hline
\end{tabular}

\section{HASIL DAN PEMBAHASAN}

Hotspot merupakan salah satu indikator adanya kejadian kebakaran hutan dan lahan di suatu wilayah. Berdasarkan rekapitulasi data hotspot hasil rekaman satelit Aqua/Terra MODIS tahun 2009 sampai dengan 2014 dapat diketahui pola sebaran hotspot di wilayah Kabupaten Rokan Hilir. Sebaran titik panas pada setiap kecamatan di Kabupaten Rokan Hilir menunjukkan bahwa rata-rata jumlah titik panas tertinggi terdapat di Kecamatan Kubu, yaitu sebesar 3.798 titik. Diikuti Kecamatan Tanah Putih terdapat 2.894 titik, Kecamatan Bangko Pusako sebanyak 2.062 titik, Kecamatan Pujud sebanyak1.501 titik, Kecamatan Bagan Sinembah sebanyak 906 titik, Kecamatan Bangko sebanyak 798 titik, Kecamatan Pasir Limau Kapas sebanyak 755 titik, KecamatanTP Tj. Melawan sebanyak 646 titik, dan Kecamatan Rimba Melintang sebanyak 421 titik. Jumlah titik panas terendah, terdapat di Kecamatan Simpang Kanan sebanyak 182 titik, Kecamatan Batu Hampar sebanyak 101 titik dan Kecamatan Sinaboi sebanyak 81 titik. Kecamatan Kubu merupakan daerah 
yang paling rawan terhadap kebakaran hutan dan lahan. Kemungkinan kebakaran hutan dan lahan di kecamatan ini terjadi akibat kegiatan pembukaan lahan untuk perkebunan sawit.

Jumlah hotspot tertinggi berada pada area dengan tutupan lahan semak belukar rawa dan hutan rawa sekunder, sedangkan jumlah hotspot paling rendah berada di area dengan tutupan lahan hutan rawa primer, pemukiman, rawa. Semak belukar rawa merupakan area dengan jumlah hotspot paling tinggi, karena kejadian kebakaran akan sangat mudah terjadi dengan tingginya jumlah bahan bakar berupa semak belukar, apalagi jika dalam keadaan kering (kadar air rendah).

Tabel 2. Perbandingan jumlah hotspot berdasarkan penutupan lahan

\begin{tabular}{|c|c|c|c|c|c|c|c|}
\hline Jenis Penutupan Lahan & 2009 & 2010 & 2011 & 2012 & 2013 & 2014 & \\
\hline Hutan Mangrove Sekunder & - & - & - & - & 5 & 2 & 7 \\
\hline Hutan Rawa Primer & 4 & 5 & 1 & 6 & 2 & 11 & 29 \\
\hline Hutan Rawa Sekunder & 94 & 77 & 288 & 405 & 817 & 665 & 2.346 \\
\hline Hutan Tanaman Industri (HTI) & 5 & 5 & 10 & 1 & 22 & 13 & 56 \\
\hline Perkebunan & 247 & 40 & 167 & 50 & 485 & 162 & 1.151 \\
\hline Permukiman & 3 & 6 & 4 & 3 & 9 & 1 & 26 \\
\hline Pertambangan & 11 & 2 & 9 & & 12 & 5 & 39 \\
\hline Pertanian Lahan Kering & 12 & 5 & 5 & 4 & 37 & 12 & 75 \\
\hline $\begin{array}{l}\text { Pertanian Lahan Kering } \\
\text { Bercampur dengan Semak }\end{array}$ & 625 & 80 & 351 & 283 & 390 & 687 & 2.416 \\
\hline Rawa & 3 & 6 & 1 & 3 & 10 & 4 & 27 \\
\hline Semak/Belukar & 20 & 3 & 16 & 4 & 17 & 14 & 74 \\
\hline Semak/Belukar Rawa & 1.087 & 430 & 981 & 683 & 1.763 & 1.362 & 6.306 \\
\hline Tanah Terbuka & 360 & 65 & 176 & 123 & 495 & 374 & 1.593 \\
\hline Total & 2.111 & 659 & 1.833 & 1.442 & 3.569 & 2.938 & 14.145 \\
\hline
\end{tabular}

Sumber : Hasil olahan (2014)

Kebakaran hutan merupakan sebuah masalah yang hampir tidak pernah usai dan mengakibatkan kerugian yang cukup besar baik dibidang ekonomi, ekologi, sosial, dan kesehatan makhluk hidup khususnya manusia. Hampir setiap tahun terjadi kebakaran hutan dan lahan $\mathrm{d}$ indonesia dan sudah dapat dipastikan 99,9\% penyebabnya adalah manusia. Kegiatan dibalik kebakaran hutan dan lahan tersebut terjadi dalam berbagai macam aktifitas baik dalam kegiatan pertanian, kehutanan maupun kegiatan lainnya (pembangunan kawasan industri, kawasan pemukiman) yang 
sesungguhnya dilarang (Saharjo, 2004).

Kebakaran hutan tersebut tidak dibatasi waktu dan lokasi tertentu dengan kata lain dapat terjadi kapan saja dan dimana saja. Oleh karena itu dalam rangka pemantauan dan penanggulangan kebakaran hutan dan lahan secara dini sangat diperlukan adanya informasi daerah rawan kebakaran. Hasil overlay antara peta kerawanan kebakaran hutan berdasarkan analisis penutupan lahan, jenis tanah, topografi, curah hujan, dan jarak pemukiman akan diperoleh peta kerawanan kebakaran hutan dan luas kelas rawan kebakaran (Tabel 3). Untuk memetakan tingkat kerawanan kebakaran hutan dilakukan perhitungan indeks kerawanan kebakaran (IK) dengan menggunakan persamaan seperti rumus pada metode penelitian.

Tabel 3. Luas Tingkat Kerawanan Kebakaran Hutan

\begin{tabular}{lrr}
\hline Tingkat Kerawanan & Luas $(\mathrm{Ha})$ & Luas $(\%)$ \\
\hline \hline Rendah & $9.152,55$ & 1,01 \\
\hline Sedang & $158.943,95$ & 17,49 \\
\hline Tinggi & $382.448,62$ & 42,08 \\
\hline Sangat Tinggi & $358.374,00$ & 39,43 \\
\hline LuasTotal a) & $908.919,12$ & 100,00 \\
\hline Sumber : Hasil olahan (2014) & &
\end{tabular}

Tabel 3 menunjukkan bahwa sebagian besar daerah Kabupaten Rokan Hilir memiliki tingkat kerawanan tinggi dan tingkat kerawanan sangat tinggi. Daerah rawan rendah memiliki luas $9.152,55$ hektar $(1,01 \%)$, tingkat rawan sedang seluas 158.943,95 hektar $(17,49 \%)$, tingkat rawan tinggi seluas 382.448,62 hektar (42,08\%) dan tingkat kerawanan sangat tinggi dengan luas $358.374,00$ hektar $(39,43 \%)$.

Tabel 4. Luas penutupan lahan pada tingkat kerawanan

Luas Tingkat Kerawanan $(\mathrm{Ha})$

\begin{tabular}{|c|c|c|c|c|c|}
\hline \multirow{2}{*}{ Tutupan Lahan } & \multirow{2}{*}{$\begin{array}{l}\text { Sangat } \\
\text { Tinggi }\end{array}$} & \multirow[b]{2}{*}{ Tinggi } & \multirow[b]{2}{*}{ Sedang } & \multirow[b]{2}{*}{ Rendah } & \multirow[b]{2}{*}{ Total } \\
\hline & & & & & \\
\hline Hutan Rawa Primer & 515,10 & - & 239,09 & 511,11 & $1.265,3$ \\
\hline Rawa & $1.427,30$ & $1.918,38$ & 79,79 & - & $3.425,4$ \\
\hline Sawah & - & $2.050,71$ & $2.122,86$ & - & $4.173,5$ \\
\hline Semak/Belukar & $1.432,52$ & $4.594,47$ & 520,98 & 7,44 & $6.555,4$ \\
\hline Permukiman & 983,74 & $3.671,01$ & $1.935,07$ & 176,61 & $6.766,4$ \\
\hline
\end{tabular}




\begin{tabular}{lrrrrr}
\hline Pertambangan & $3.428,00$ & $4.031,21$ & 0,01 & - & $7.459,2$ \\
\hline Hutan Tanaman Industri $(\mathrm{HTI})$ & $7.652,03$ & 93,40 & $1.009,81$ & - & $8.755,2$ \\
\hline Hutan Mangrove Sekunder & - & 898,71 & $9.123,62$ & $5.571,90$ & $15.594,23$ \\
\hline Tubuh Air & 874,40 & $7.905,66$ & $9.190,16$ & 423,85 & $18.394,07$ \\
\hline Pertanian Lahan Kering & $3.212,14$ & $23.311,75$ & $15.413,1$ & $1.435,24$ & $43.372,25$ \\
\hline Tanah Terbuka & $38.483,26$ & $15.988,72$ & 203,73 & 0,00 & $54.675,71$ \\
\hline Hutan Rawa Sekunder & $54.950,36$ & $41.685,84$ & $16.582,8$ & 30,22 & $113.249,31$ \\
\hline $\begin{array}{l}\text { Pertanian Lahan Kering } \\
\text { Bercampur dengan Semak }\end{array}$ & $54.665,24$ & $59.889,08$ & $28.338,3$ & 923,01 & $143.815,63$ \\
\hline Semak/Belukar Rawa & $145.602,92$ & $64.548,60$ & $18.155,6$ & 255,99 & $228.563,11$ \\
\hline Perkebunan & $44.817,74$ & $151.861,05$ & $56.028,9$ & 146,46 & $252.854,16$ \\
\hline Total & $358.044,75$ & $382.448,60$ & $158.943,92$ & $9.481,84$ & $908.919,12$ \\
\hline \multicolumn{1}{c}{ Sumber: $:$} & & & &
\end{tabular}

Sumber : Hasil olahan (2014)

Tabel 4 menunjukkan ada empat tingkat kerawanan kebakaran hutan dan lahan di Kabupaten Rokan Hilir yaitu tingkat kerawanan sangat tinggi, tinggi, sedang dan rendah. Wilayah kebakaran hutan dan lahan dengan tingkat kerawanan sangat tinggi memiliki luas $358.044,75$ ha, tingkat kerawanan tinggi dengan luas $382.448,60$ ha, tingkat kerawanan sedang dengan luas 158.943,92 ha dan tingkat kerawanan rendah dengan luas $9.481,84$ ha.

Tingkat kerawanan sangat tinggi di dominasi dengan tutupan lahan semak belukar rawa, pertanian lahan kering bercampur semak, hutan rawa sekunder, tanah terbuka dan perkebunan. Sedang tingkat kerawanan rendah di dominasi dengan tutupan lahan hutan mangrove dan hutan rawa primer. Peta tingkat kerawanan kebakaran hutan dan lahan di Kabupaten Rokan Hilir dapat dilihat pada Gambar 1.

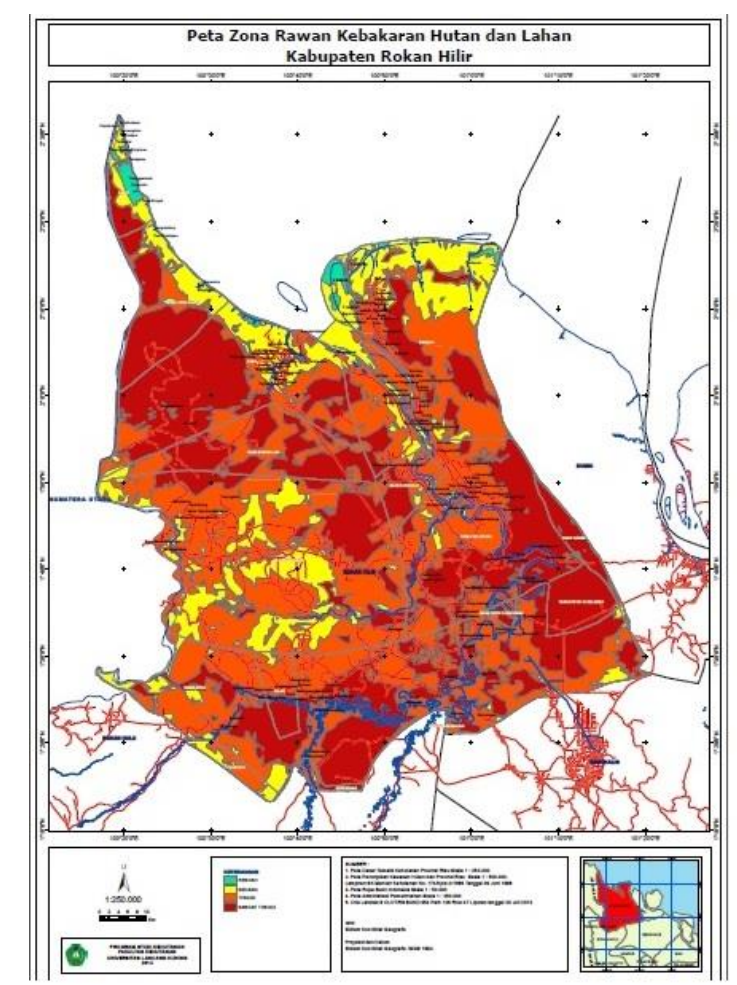

Gambar 1. Peta tingkat kerawanan kebakaran hutan dan lahan di Kabupaten Rokan Hilir

\section{KESIMPULAN}

Tingkat kerawanan Kebakaran di Kabupaten Rokan Hilir terbagi atas empat kelas yaitu rawan sangat tinggi, rawan tinggi, rawan sedang, dan rawan rendah. Sebagian besar daerah 
Kabupaten Rokan Hilir memiliki tingkat kerawanan tinggi dan tingkat kerawanan sangat tinggi. Daerah tingkat rawan rendah memiliki luas 9.152,55 hektar (1,01\%), tingkat rawan sedang seluas 158.943,95 hektar $(17,49 \%)$, tingkat rawan tinggi seluas $382.448,62$ hektar $(42,08 \%$ ) dan tingkat kerawanan sangat tinggi dengan luas $358.374,00$ hektar $(39,43 \%)$.

Peta daerah rawan kebakaran hutan dan lahan akan berguna dalam memberikan informasi keruangan tentang potensi ancaman bahaya kebakaran hutan dan lahan, sehingga dapat dibuat statu sistem peringatan dini pada wilayah tersebut, khususnya pada saat atau menjelang musim kemarau

\section{DAFTAR PUSTAKA}

Arianti, I. 2006. Pemodelan Tingkat Dan Zona Kerawanan Kebakaran Hutan dan Lahan Menggunakan Sistem Informasi Geografis Di Sub Das Kapuas Tengah Propinsi Kalimantan Barat. Tesis. Bogor : Sekolah Pascasarjana Institut Pertanian Bogor.

Barus, B. dan K. Gandasasmita, 1996. Penentuan Zonasi Rawan Kebakaran Pulau Sumatera Tahun 1996 dengan Sistem Informasi Geografi. Sekretariat Koordinasi Nasional Pengendalian Kebakaran Lahan. Jakarta.

Booyanuphap J. 2001. GIS BasedMethod in Developing Wildfire Risk Model: A Case Study in Sasamba,
East Kalimantan , Indonesia (Thesis). Bogor : Graduated Program, Bogor Agricultural University.

Chuvieco, E and F.J. Salas. 1996. Mapping The Spatial Distribution of Forest.

Hardy, Colin c. 2005. Wildland fire hazard and risk: Problem, definition, and context.

Forest Ecology and Management. 73-82.

Hoffman A. A, 2000. Production of a Fire Hazard Map for East Kalimantan.

Zebris GIS + Consulting. Tidak Dipublikasikan.

LAPAN [Lembaga Penerbangan dan Antariksa Nasional]. 2004. Sebaran Titik Panas Menurut Penggunaan Lahan di Pulau Sumatera. SIMBA- LAPAN.

Purbowaseso. 2004. Pengendalian Kebakaran Hutan. Rineka Cipta. Jakarta.

Ruecker, G, 2002. Consulting and Software Development to Produce a Dynamic Fire Danger Map for East Kalimantan. IFFM Document Report (Temporary).

Saharjo, B. H. 2004. Adaptasi Rencana Pembangunan

Kehutanan

Dibawah

Bayang-bayang

Perubahan Iklim. Laboratorium Kebakaran Hutan danLahan. Fakultas Kehutanan IPB. Bogor.

Solichin, L. Tarigan, P. Kimman, B. Firman, dan R. Bagyono. 2007. Pemetaan Daerah Rawan Kebakaran.

Syaufina L. 2008. Kebakaran Hutan dan Lahan di Indonesia: Perilaku Api, Penyebab, dan Dampak Kebakaran. Malang: Bayu Media. 